\title{
TOWARD THE BEST STRATEGY IN MINIMIZING THE SPREAD OF DRUG USERS
}

\author{
Mochamad Soelton ${ }^{1 *}$, Tati Nugrahati ${ }^{1}$, Yanto Ramli ${ }^{1}$, Dudi Permana ${ }^{1}$, and \\ Deden Kurniawan ${ }^{1}$ \\ Universitas Mercu Buana, Indonesia \\ *soelton@mercubuana.ac.id
}

\begin{abstract}
This theme aimed to minimize the spread of Narcotics users at the student level, in the data of the National Narcotics Agency (BNN), cases of drug use by the drug users up to March 2018 amounted to 6.4 Million. The data is alarming because along with the increase in drug cases (especially among the young people and the children). The spread of drugs is easy because the elementary school children have also started trying to smoke cigarettes. Although the government in the Child Protection Act number 23 of 2002 in article 20, it has been stated that the State, the government, the community, the family, and the parents are obliged and responsible for the implementation of child protection (see more fully in the Child Protection Act). However, the child protection from drugs is still far from expectations. A lot of elementary school and junior high school age of children are also trapped in drugs; the drug addicts are generally between the ages of 11 and 24. At the productive age or student age, the students who take drugs usually begin with their introduction to cigarettes. From this habit, their association continues to increase, especially when the students join with the people who have become the drug addicts. At the beginning they only try to use the drugs, but then they will depend on them.
\end{abstract}

Keywords: Narcotics, student, government

\section{INTRODUCTION}

Based on the data from the National Narcotics Agency (BNN), the cases of drug use by the drug users with elementary education levels up to 2007 totaled 12,305. This datum is so alarming because along with the increase in drug cases (especially among young people and children, the spread of HIV / AIDS is increasing and threatening. The spread of drugs is becoming easier because the elementary school children have also started trying to smoke cigarettes. The drug dealers infiltrate addictive substances (substances that cause addictive effects) into the tobacco rolls. This confirms that currently the child protection from the dangers of drugs is still not effective enough. Although the government in the Child Protection Act number 23 of 2002 in article 20 has stated that the state, the government, the community, the family, and the parents are obliged and responsible for the implementation of child protection (see more fully in the Child Protection Act), but the child protection from drugs is still far from the expectations.

Drugs are a critical and complicated issue that cannot be solved by only one party. That is because drugs are not just an individual problem but also everyone's problems. Finding the right solution is a big job that involves and mobilizes all parties, including the government, the non-governmental organizations (NGOs), and the local communities. It is very essential to work together in order to protect children from the dangers of drugs and provide useful alternative activities along with explaining them to children about the dangers of drugs and the negative consequences they will receive. Children need information, strategies, and abilities to prevent them from the dangers of drugs or also reduce the impact of the dangers of drugs from drug use from other people. One of the efforts in handling the danger of drugs is to do a program that focuses on school-age children.

In Indonesia, the development of drug addicts is increasing rapidly. The drug addicts are generally between 11 and 24 years old. This means that the age is the productive age or the student age. At first, students who take drugs usually begin with an introduction to cigarettes. Because this smoking habit seems to have become a natural thing among the students today. From this habit, the association 
continues to increase, especially when the students join the environment of people who have become the drug addicts. At the beginning, they only try and then gradually they depend on them.

Poverty is still the estuary of all social problems that exist in Indonesia, even it is also found in other countries in the world. The issue of poverty is actually a global issue in which the poverty rate is high. The BPS data in the year of 2012 recorded that the Indonesia's poor population was 29.13 million people (11.96\%). The poverty alleviation achieved only 0.53 percent or only 0.89 million people were successfully alleviated through the poverty alleviation programs that were synergized through all across Ministries. Due to the fact that the rate of reduction in the amount of poverty that can be overcome is small, the poverty reduction needs to get the attention of all parties, as stated in Law No. 13 of 2011 concerning the handling of the poor, in which the handling of the poor is the responsibility of the government, the local government, and the society. One social problem that leads to poverty is the problem of the drug use. Based on the results of the preliminary observations and the discussions, the main problem formulation in this program is "how to develop an adaptive motivational seminar approach to help prevent early drug abuse among the students?".

In general, the objectives of this program are to develop a more complete and comprehensive understanding for the participants to understand the importance of the basic concepts and the applications regarding the meaning of drugs, the types of drugs, and the impact of drug use on the students, to understanding a more adaptive approach in the development of personal character and nation (national and personal character building) and furthermore to increase motivation for selfprevention of the drug abuse, and to encouraged to be a motivator for other young people, especially peers, so as to provide a positive influence to minimize and even help the government to zero point in drug abuse.

\section{LITERATURE REVIEW}

The drug dependence can be interpreted as a condition that encourages someone to take illegal drugs repeatedly or continuously. If someone does not use it, he will feel addicted (sakau) which results in an even uncomfortable feeling. Even worse he will have the feeling of pain (Joseph, 2004:34).

Besides that, the impact of narcotics abuse according to the National Narcotics Agency (2010), narcotics can be divided into 3 types, namely:

1. Depressant, that is something which suppresses the central nervous system and reduces the functional body so that the user feels numb; it can even make the users to be asleep and self-defeats. When overdosed, it can lead to death. The depressant drug types include opioda, various derivatives such as morphine, and heroin. The present popular example is the Putaw.

2. Stimulants, something which stimulates body functions and increase excitement as well as awareness. Stimulant types include: Caffeine, Cocaine, and Amphetamine. The examples that are now often used are the Shubu and the Ecstasy.

3. Hallucinogens, the main effect of which is changing the perspective or having hallucinations. The hallucinogens mostly come from the plants such as mescaline which is from cactus and psilocybin which is from mushrooms. In addition there are also those that are mixed in the laboratory such as the LSD. The most widely used is marijuana.

If the narcotics are used continuously or if it exceeds the prescribed dose, it will cause dependence. This addiction will cause physical and psychological disorders, due to the damage to the central nervous system (CNS) and to the organs such as the heart, the lungs, the liver, and the kidneys.

The impact of narcotics abuse on a person depends on the type of narcotics that is used and it will influence the personality of the user and the situation or condition of the user. In general, the impact of narcotics addiction can be seen in a person's physical, psychological, and social condition.

Physical impact:

1. Disorders of the nervous system (neurological) such as: convulsions, hallucinations, impaired consciousness, and peripheral nerve damage.

2. Disorders of the heart and the blood vessels (cardiovascular) such as: acute infection of the heart muscle, and the circulatory disorders.

3. Skin disorders (dermatological) such as: landings (abscesses), allergies, and eczema. 
4. Disorders of the lungs (pulmonary) such as: suppression of respiratory function to difficulty breathing, and hardening of the lung tissue.

5. Frequent headaches, nausea and vomiting, stiffness, increased body temperature, liver wasting, and difficulty sleeping.

6. Impacts on the reproductive health are endocrine disorders, such as: decreased function of reprouduction hormones (estrogen, progesterone, testosterone), and sexual dysfunction.

7. Impacts on the adolescent reproductive health include changes in menstrual periods, menstrual irregularities, and amenorhoe (no menstruation).

8. For the drug users through needles, especially for sharing needles and syringes, the risk is contracting diseases such as hepatitis B, C, and HIV which until now it has no cure.

9. Drug abuse can be fatal when there is an Over Dose that is the drug consumption that exceeds the body's ability to receive it. Over doses can cause death

Psychic Impact:

1. Being Lazy learning, careless, often tense and nervous

2. Losing self-confidence, apathy, fantasy, and suspicion

3. Being agitative, becoming violent, and being brutal behavior

4. Having difficulty concentrating, feeling upset and feeling depressed

5. Having the tendency to hurt yourself, feeling insecure, even commiting suicide

Social Impact:

1. Mental, anti-social and immoral disorders, being isolated by the environment

2. Troubling and becoming a family burden

3. Disrupted education and having a gloomy future.

Physical, psychological, and social impacts are closely related. The physical dependence will result in tremendous pain (withdrawal) in the event of a drug breakdown (not taking drugs on time) and the psychological encouragement in the form of a very strong desire to consume. These physical and psychological symptoms are also related to social symptoms such as the urge of deceiving parents / friends, stealing, being angry, being manipulative, and others.

\section{METHOD}

This training uses the experiential learning methods with the interactive communication techniques, the dialogue, the discussion, the role play / games, where the participants are introduced to the concept, then directly involved feeling, experiencing, discussing the process and the results of this training to know, understand, realize and be expected to apply the results motivational seminar to help prevent and overcome the drug abuse.

The training was held in collaboration with the Faculty of Economics and Business, Mercu Buana University (UMB) with SMK PGRI 5 Pegadungan, Kalideres, West Jakarta. UMB helped provide the speakers, the seminar handouts, the pre-post test, the evaluation, and the snack materials, while the SMK PGRI 5 helped to condition the participants, provided a place (room), and equipment / training equipment. The training participants were 120 stuedents of the PGRI 5 Pegadungan Kalderes, West Jakarta (representing all existing classes). 
Activity Process

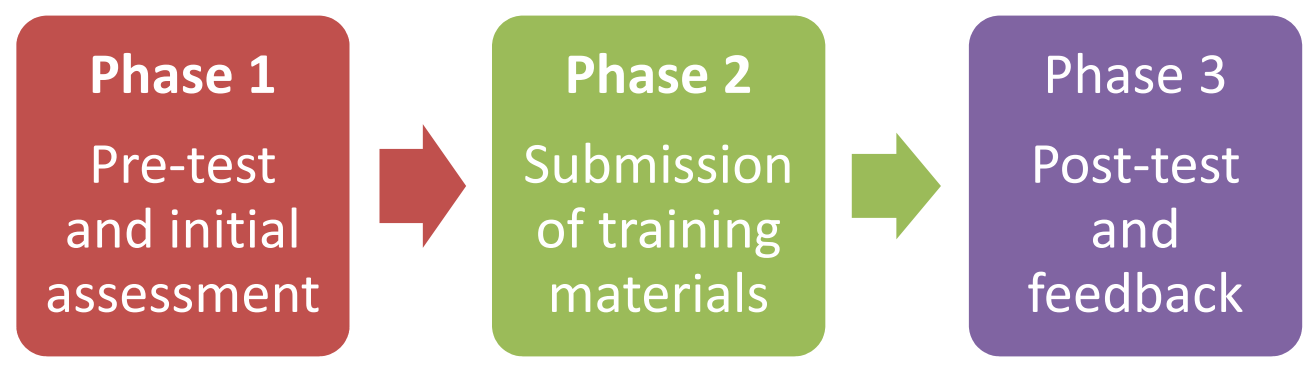

Phase 1: Pre-test and initial assessment of participants

After the opening ceremonial event and before the material was delivered, the participants were asked to fill out the questionnaire as a pre-test. The initial assessment of the participants was carried out by filling out the training registration form.

\section{Phase 2: Submission of training materials by instructors}

Training material consist of Complexity Regarding Drugs and the Impact of Abuse and Nation and Personal Character Building as a Model and Strategy to Prevent Drug Abuse.

\section{Phase 3: Post-test and feedback}

Before closing, the participants were asked to fill in the post-test, and evaluate the event, messages and the impressions from the participants as feedback.

\section{RESULTS AND DISCUSSION}

The basic understanding of the meaning of drugs and their types and their impact on the younger generation as the hope of the nation and the state is very important and urgent. Narcotics are an abbreviation of the narcotics, the psychotropic substances, and the addictive substances. Drugs are medicine, the ingredients, the substances that are drunk / smoked / swallowed, or injected and it can cause dependence and affect the work of the brain, as well as the vital functions of other organs (the heart, the blood circulation, the breathing, etc.) Narcotics are substances or drugs derived from plants or non-plants, both synthetic and semisynthetic which cause a decrease or change in consciousness and eliminate or reduce the pain and they can cause dependence (Law No.27 / 1997) Meanwhile, according to WHO what is meant by the definition of this drug definition is a substance which, if inserted into the body, will affect physical and / or psychological function (except food, water, or oxygen).

The danger of drugs for the addicts (young generation) is very much and if it is not immediately stopped the habit of consuming drugs, this will worsen the health status of the users themselves slowly but surely, and certainly it can endanger the survival of this nation in the future. Youth as a generation that is expected to be the nation's successor, the more fragile the day is undermined by the addictive substances of neurological destruction, so that the young man cannot think clearly. As a result, the generation of hope for a strong and intelligent nation will only remain a memory. The target age of drug users is the student age, which ranges from 11 to 24 years. This indicates that the dangers of drugs can target our students at any time. The effects of drug use can be in various forms, including the following: 1) Causing a decrease or even change in consciousness, 2) Eliminating the senses, 3) Reducing to relieve pain, 4) Adding dependency / addiction. The greatest danger of drugs for health is the effect of the drug dependence itself. Because with the bad effects caused to drug addicts is the desire to always use it repeatedly.

The values of life that are given are the character and the good character building programs that are integrated with the entire learning process of the students, starting from their home, their school, their extra-curricular activities, their social activities, and other self-development activities. The value education will perfect the formal education of the students get through the transfer of the knowledge and the skills in school. 
It is increasingly recognized that the transfer of knowledge and skills for the students without prioritizing value transfer will only give birth to the students who are skillfully cognitive and skillful, but their fundamental weaknesses in interpreting and applying life values, including: the importance of respect for the parents and the teachers, respect for older people, the discipline, the enthusiasm for learning, the identity, the future vision, the achievement motivation, the cooperation, the willingness to help others, the self-integrity, and a number of other positive characters needed for success.

In building a value-based school culture that is the central mission of the education at this time, various approaches to character and character education are needed, both with those that are integrated with the student learning curriculum and with the specific approaches that are given with certain methods. Specific approaches with certain methods are carried out in the form of training using the experiential learning methods. This motivational seminar given to SMK PGRI 5 Pegadungan, Kalideres, West Jakarta students was a stimulus, and became meaningful when the students who took part in the training were committed to practicing it in the study and the daily life. Therefore, this value training was designed in such a way as to help students who were trained to have a strong reflective attitude from every action in the learning process experienced, both at school, in the family, in the social environment, in the community, within the nation, and the country.

This value building training in the character building used a heroic leadership approach based on the four pillars, namely: self-awareness, responsiveness, love, and a burning spirit.

\section{CONCLUSION}

From all stages of the community service activities that have been carried out, it can be concluded that the activities of exposure, counseling, introduction to the danger of the Nafza have an impact on the alertness of all teachers, parents, and most importantly all students in recognizing the early negative influences and the dangers in the Nafza.

Another important thing really requires a form of cooperation, commitment, and consistency in every order of the nation's elements, both in the personal, institutional, and social order. Matters to prevent the drug use include never try at any level, with any type, and under any reasons, look for safe relationships, in a safe place with safe people, and at a safe time, get sincere affection from the family by caring for one another, loving one another, and needing each other. Develop this affection for your relatives, close friends, and other friends, beware of anyone by living in a reasonable life. Say NO to Drugs, and bring yourself closer to the God Almighty by diligently carrying out the worship and asking strengths for Him. Without the power of the God, humans are full of weaknesses.

Illegal drugs are not the right answers to all problems, and on the contrary, they will cause a much bigger problem. Drug users are people who experience a large loss and they may end in death. The best action to overcome the danger of drugs is to prevent the involvement with the drug itself because the prevention is far better than the treatment.

\section{REFERENCES}

Abdul Razak \& Sayuti. (2009. Remaja dan Bahaya Narkoba. Jakarta, Prenada.David, Gough, W.G. (1998). Character is destiny: the value of personal ethics in everyday life, USA: Forum, Prima Publishing.

Lowney , C. (2009). Heroic living (terjemahan). Jakarta: Gramedia Pustaka Utama.

Murti, Hari. (2011). Bahaya Narkoba dikalangan Remaja. Jakarta, Mitra.

Manurung, R.D.A. (2011). Efektivitas model pendekatan kepemimpinan heroik dalam pelatihan "personal character building bagi para mahasiswa di jakarta.proceeding, Lustrum Ubaya, Surabaya. 
Manurung, R.D.A. (2013). Efektivitas model pendekatan kepemimpinan heroik dalam pelatihan "personal character building bagi para siswa di jakarta. Hasil Penelitian (belum diterbitkan), Jakarta : UMB.

Mulyana, E.H. (2012). Manajemen pendidikan karakter. Jakarta : Bumi Aksara.

R.F. (2015). Strategic Management: A Competitive Advantage Approach, Concepts.15th Edition. Prentice Hall.

Taylor, E.S., Peplau, A.L. \& Sears, O.D. (2009). Social psychology. Los Angeles: Prentice 